\title{
Mutagen-induced chromosome instability in farm animals*
}

\author{
B. Danielak-Czech ${ }^{1}$ and E. Słota \\ Department of Immuno- and Cytogenetics, \\ National Research Institute of Animal Production \\ Krakowska 1, 32-083 Balice, Poland
}

(Received 7 July 2003; revised version 8 January 2004; accepted 9 April 2004)

\begin{abstract}
The frequencies of spontaneous and in vitro mutagen-induced unstable chromosomal lesions were compared in the groups of subfertile cows, ewes and sows (test groups) as well as the animals without any reproductive disturbances (control groups). The mean percentage of 5-azacytidineand bromodeoxyuridine-induced defects differed statistically between the test and control groups ( $\mathrm{P} \leq 0.01$ in cattle, $\mathrm{P} \leq 0.05$ in sheep and pigs). In the groups of animals with reproductive problems the number of defects observed in some chromosomes exceeded the expected values (calculated according to the relative chromosome length), but only in the case of X chromosome differed at the level of statistical significance. Moreover, the groups of cows analysed differed significantly as regards the number of chromatid breaks/gaps at the Xq2.4 and Xq3.1 fragile sites. The excessive chromosome instability in subfertile farm animals, particularly the X-specific loci, may result in inappropriate expression of genes determining reproductive traits as well as in the increased rate of aneuploid germ cells related to prenatal and perinatal mortality.
\end{abstract}

KEY WORDS: chromosome instability, fragile sites, fragile X, subfertility, farm animals

\footnotetext{
* This work was conducted as part of statutory activity of National Research Institute of Animal Production, Project No. 3202.1

${ }^{1}$ Corresponding author: e-mail: bczech@izoo.krakow.pl
} 


\section{INTRODUCTION}

Structural chromosome instability is considered to reflect DNA damages, which, if not repaired, result in gene or chromosome mutations. Exposure to environmental genotoxic agents was found to increase frequency of spontaneous unstable karyotype lesions, preferentially affecting some chromosomes or their regions (Bryant, 1997). Specific in vitro lymphocyte culture conditions or chemical treatment with mutagens or clastogens were also proved to cause a statistically significant recurrence of structural defects (breaks/gaps) at the same chromosome points, regarded as fragile sites (Sutherland et al., 1996). Mammalian fragile sites, classified according to the population extent and induction method, include the groups of the 5-azacytidine (5-AZA) and bromodeoxyuridine (BrdU)-sensitive ones, resulting from thymidine/cytidine substitutions in DNA (Sutherland et al., 1985).

There are no reports on 5-AZA-dependent karyotype instability of farm animals and only a few papers concern the expression of BrdU-sensitive sites on chromosomes of phenotypically normal cattle, sheep and pigs (Di Berardino et al., 1983; Matejka et al., 1995; Rønne, 1995).

The aim of the present study was to compare the frequencies of spontaneous as well as 5-AZA- and BrdU-induced chromosomal defects (breaks / gaps) in the groups of fertile and subfertile cows, ewes and sows with pointing out the most fragile chromosomes and chromosome regions.

\section{MATERIAL AND METHODS}

Cytogenetic evaluation was performed in populations of healthy (including normal exterior) 2- to 5-year-old Black-and-White cows, Polish Heath ewes and Polish Landrace sows. The animals (chosen from the same herds at the same period and not exposed to any special chemical or physical environmental factors) were divided into test and control groups (12 animals in each group of the same age as well as feeding and breeding system) with regard to individual reproductive efficiency.

The test groups of cows and sows were composed of the animals with reproductive problems expressed by high services/conception index, long calving or farrowing interval and increased perinatal mortality (early embryonic mortality, foetus abortion, stillbirth, after birth mortality) resulting in considerable losses of calves and piglets (\%). The group of test ewes consisted of animals infertile due to ineffective matings (100\% in two years). The control groups included cows, sows and ewes having normal reproductive performance. 
Lymphocytes were cultured in RPMI 1640 medium supplemented with $10 \%$ of foetal bovine serum, penicillin $(100 \mathrm{IU} / \mathrm{ml})$, streptomycin $(100 \mu \mathrm{g} / \mathrm{ml})$, and pokeweed mitogen $(2.5 \mu \mathrm{g} / \mathrm{ml})$. Both control and experimental cultures were conventionally harvested after colchicine treatment $(0.4 \mu \mathrm{g} / \mathrm{ml})$ in $72 \mathrm{~h}$. The experimental cultures have been exposed for $6 \mathrm{~h}$ prior to harvest to $50 \mu \mathrm{g} / \mathrm{ml}$ of 5-AZA and $50 \mu \mathrm{g} / \mathrm{ml} \mathrm{BrdU}$.

The slides were stained sequentially using conventional Giemsa staining method and GTG banding technique and 50 metaphases per culture were scored for breaks/gaps or chromosomal rearrangements.

Karyotypes and locations of fragile sites have been assigned according to the international cattle, sheep and pig karyotype standards (Gustavsson, 1988; Di Berardino et al., 2001).

Statistical analysis of results was performed by the Kołmogorow-Smirnow and Chi square tests using STATISTICA, version 5.1 computer system.

\section{RESULTS}

The average values of some reproductive parameters are shown in Table 1 .

TABLE 1

Reproductive performance of investigated animals

\begin{tabular}{|c|c|c|c|}
\hline Species & $\begin{array}{c}\text { Group } \\
\mathrm{n}=12\end{array}$ & Reproductive parameters & Rate \\
\hline \multirow[t]{6}{*}{ Cattle } & Test & services/conception, $\%$ & 4.60 \\
\hline & & calving interval, months & 16.40 \\
\hline & & $\begin{array}{l}\text { losses of calves (early dead embryos/ foetuses aborted/ } \\
\text { stillborn/dead after birth) \% }\end{array}$ & 20.00 \\
\hline & Control & services/conception, $\%$ & 1.30 \\
\hline & & calving interval, months & 12.50 \\
\hline & & $\begin{array}{l}\text { losses of calves (early dead embryos/ foetuses aborted/ } \\
\text { stillborn/ dead after birth), \% }\end{array}$ & 6.20 \\
\hline \multirow[t]{2}{*}{ Sheep } & Test & ineffective matings in 2 years, $\%$ & 100 \\
\hline & Control & ineffective matings in 2 years, $\%$ & 0 \\
\hline \multirow[t]{6}{*}{ Pigs } & Test & services/conception, $\%$ & 3.70 \\
\hline & & farrowing interval, months & 8.60 \\
\hline & & $\begin{array}{l}\text { losses of piglets (early dead embryos/ foetuses aborted/ } \\
\text { stillborn/dead after birth), } \%\end{array}$ & 12.00 \\
\hline & Control & services/conception, $\%$ & 1.30 \\
\hline & & farrowing interval, months & 6.50 \\
\hline & & $\begin{array}{l}\text { losses of piglets (early dead embryos/ foetuses aborted/ } \\
\text { stillborn/ dead after birth), \% }\end{array}$ & 6.70 \\
\hline
\end{tabular}


The results of cytogenetic evaluation of the animal groups compared are presented in Table 2. The expression of chromosome fragility was almost similar for both induction agents with slightly increased numbers of unstable lesions obtained after exposure to BrdU. The mean percentages of defects induced differed significantly between the test and control groups $(\mathrm{P} \leq 0.01$ in cattle and $\mathrm{P} \leq 0.05$ in pigs and sheep), whereas the frequencies of spontaneous lesions (generally higher in the test herds) only within the population of cows $(\mathrm{P} \leq 0.05)$.

TABLE 2

Frequency of spontaneous and induced breaks/gaps in cattle, sheep and pigs

\begin{tabular}{llrrr}
\hline & & Spontaneous & & \multicolumn{2}{c}{ 5-AZA- and BrdU-sensitive breaks/gaps } \\
\cline { 3 - 5 } Species & Group & $\mathrm{n}=12$ & 5-AZA conc. $-50 \mu \mathrm{g} / \mathrm{ml}$ & $\begin{array}{c}\text { BrdU conc. }-50 \mu \mathrm{g} / \mathrm{ml} \\
\text { time exposure }-6 \mathrm{~h}\end{array}$ \\
\cline { 3 - 5 } & & mean \% SD & \multicolumn{2}{c}{ mean \% SD } \\
\hline \multirow{2}{*}{ Cattle } & test & $5.02^{* *} \pm 2.15$ & $54.12^{* *} \pm 12.11$ & $60.08^{* *} \pm 14.53$ \\
& control & $3.00 \pm 1.89$ & $36.15 \pm 10.05$ & $39.77 \pm 14.22$ \\
\multirow{2}{*}{ Sheep } & test & $2.86 \pm 2.00$ & $45.14^{*} \pm 11.11$ & $47.33^{*} \pm 13.03$ \\
& control & $1.99 \pm 1.12$ & $31.94 \pm 10.35$ & $33.40 \pm 8.99$ \\
\multirow{2}{*}{ Pigs } & test & $4.20 \pm 2.98$ & $40.39^{*} \pm 12.44$ & $43.72 * \pm 10.10$ \\
& control & $2.88 \pm 2.02$ & $27.66 \pm 10.25$ & $32.10 \pm 8.55$ \\
\hline
\end{tabular}

$*$ - $\mathrm{P} \leq 0.05$

$* *-\mathrm{P} \leq 0.01$

The highest percentages of both in vivo and in vitro induced breaks/gaps have been observed in karyotype of cows, which may suggest a greater chromosome instability or susceptibility to 5-AZA or BrdU exposure in cattle than in sheep and pigs. The percent of aberrations in 100 cells shown in Table 2 can be also expressed as break per cell values (100 times lower, respectively), applied often to evaluate genotoxic consequences of environmental factors. The results obtained for control groups corresponds to known effects of environment with minimum contamination, whereas the parameters found for test groups can be compared with those defined for farm animals populations under conditions of chemical pollution (Rubeš et al., 1992). The differences between groups studied, in spite of the same of 5-AZA and BrdU dosage used for in vitro experiment result probably from not even individual ability to repair genome structure damages.

The mean numbers of defects observed in particular chromosomes, both the control' and test' groups, were revealed generally did not exceed the expected values (corresponding to the relative chromosome length), excluding single autosomes and $\mathrm{X}$ chromosome in all the groups of subfertile animals. The values 
found for highly unstable chromosome No. 1 and $X$ in cattle, 9 and $X$ in sheep, 13 and $\mathrm{X}$ in pigs are presented in Table 3 . The only percentages of $\mathrm{X}$ chromosome lesions compared were found to differ statistically in the test group of cows $(\mathrm{P} \leq 0.01)$, ewes and sows with reproductive problems $(\mathrm{P} \leq 0.05)$. The frequency of the spontaneous cattle $\mathrm{X}$ lesions observed was also determined to be non-proportional to the expected one $(\mathrm{P} \leq 0.05)$.

TABLE 3

The excessively 5-AZA- and BrdU-sensitive chromosomes and chromosome regions in the test groups of farm animals

\begin{tabular}{|c|c|c|c|c|c|c|}
\hline \multirow{4}{*}{ Species } & \multirow{4}{*}{$\begin{array}{c}\text { Chromo- } \\
\text { some } \\
\text { No. }\end{array}$} & \multirow{4}{*}{$\begin{array}{c}\text { Relative } \\
\text { length } \\
\%\end{array}$} & \multirow{3}{*}{$\begin{array}{c}\text { Sponta- } \\
\text { neous } \\
\text { break/gaps }\end{array}$} & \multicolumn{2}{|c|}{$\begin{array}{c}\text { 5-AZA- and BrdU-induced } \\
\text { breaks/gaps }\end{array}$} & \multirow{4}{*}{$\begin{array}{l}\text { Chromosome } \\
\text { regions }\end{array}$} \\
\hline & & & & $\begin{array}{c}\text { 5-AZAconc. } \\
50 \mu \mathrm{g} / \mathrm{ml}\end{array}$ & $\begin{array}{c}\text { BrdU conc. } \\
50 \mu \mathrm{g} / \mathrm{ml}\end{array}$ & \\
\hline & & & & \multicolumn{2}{|c|}{ time exposure $-6 \mathrm{~h}$} & \\
\hline & & & $\mathrm{ob} / \mathrm{ex}$ & $\mathrm{Bb} / \mathrm{ex}$ & ob/ex & \\
\hline \multirow[t]{2}{*}{ Cattle } & 1 & 5.8 & $0.99 / 0.28$ & $4.97 / 3.34$ & $5.23 / 3.66$ & $1 \mathrm{q} 2.5$ \\
\hline & $\mathrm{X}$ & 5.4 & $1.35 / 0.26^{*}$ & $7.53 / 3.06^{* *}$ & $8.69 / 3.30 * *$ & $\begin{array}{l}\mathrm{Xp} 2.2, \mathrm{Xq} 1.2 \\
\mathrm{Xq} 2.4^{*}, \mathrm{Xq} 3.1^{*}\end{array}$ \\
\hline \multirow[t]{2}{*}{ Sheep } & 9 & 3.7 & $0.16 / 0.10$ & $2.14 / 1.63$ & $2.55 / 1.70$ & $9 \mathrm{q} 1.1$ \\
\hline & $\mathrm{X}$ & 5.9 & $0.30 / 0.16$ & $6.01 / 2.75^{*}$ & $6.28 / 3.44 *$ & $\mathrm{Xq} 1.1, \mathrm{Xq} 3.2 / 3.3$ \\
\hline \multirow[t]{2}{*}{ Pigs } & 13 & 8.2 & $0.52 / 0.26$ & $3.57 / 3.42$ & $4.03 / 3.95$ & $13 q 4.1$ \\
\hline & $\mathrm{X}$ & 5.2 & $0.19 / 0.14$ & $5.20 / 2.25^{*}$ & $5.58 / 2.45^{*}$ & $\mathrm{Xq} 2.2$ \\
\hline
\end{tabular}

ob - number of observed breaks/gaps

ex - number of expected breaks/gaps

* - $\mathrm{P} \leq 0.05$

$* *$ - $\mathrm{P} \leq 0.01$

The highly expressive autosomal and X-specific fragile sites in the groups of test animals are given in Table 3 and shown in Figure 1. In the case of the groups of cows compared the percentages of breaks/gaps at the Xq2.4 and Xq3.1 fragile sites were found to differ at the statistically significant level $(\mathrm{P} \leq 0.05)$.

The autosomal and $\mathrm{X}$-specific fragile sites in cattle, sheep and pigs have been found to occur commonly with frequency of up to $60 \%$ in the groups as well as the population studied. The animals did not display any stable chromosome aberrations. 


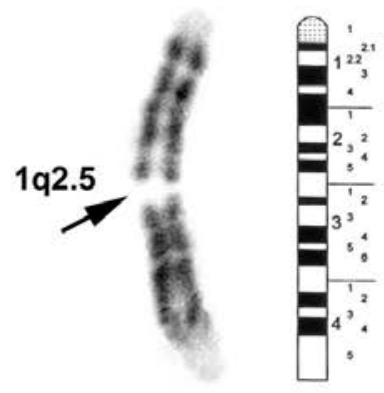

1

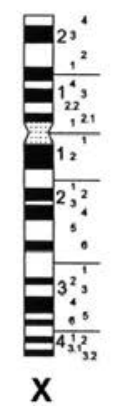

CATTLE

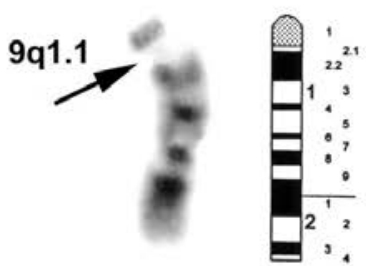

9
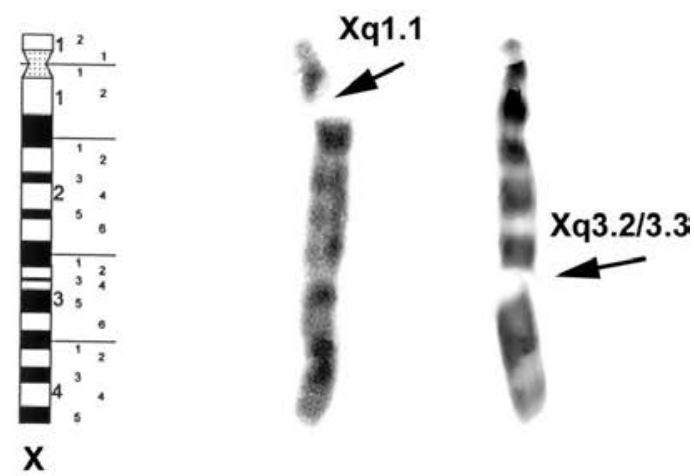

SHEEP
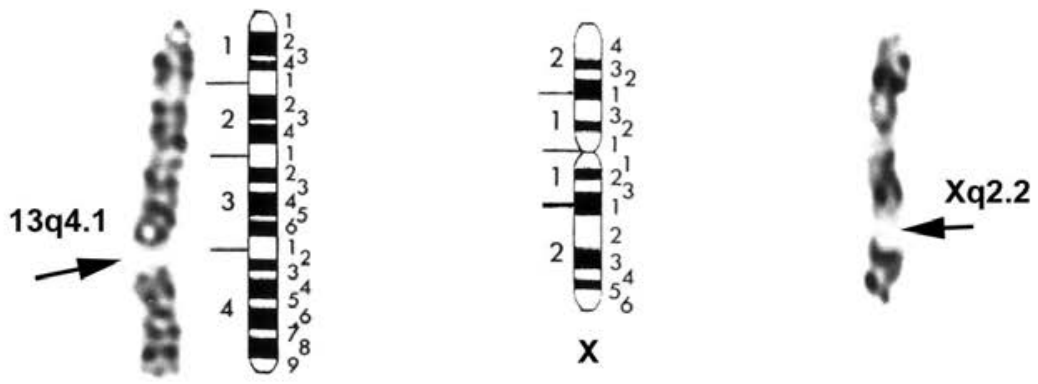

13

\section{$\mathrm{Xq1.2}$}

Xq2.4

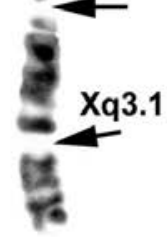

$\mathrm{Xq} 3.1$ 


\section{DISCUSSION}

Structural genome lesions are known to be the consequence of exposure to a variety of environmental mutagens, which due to specific karyotype or chromosome affinity may have phenotypic implications. Controlled in vitro experiments with high dosages of chemical agents changing genome structure, e.g., thymidine substitutions, is usually applied in humans and other mammals to determine cause and effects relationships of individual instability.

The clastogenic effects on farm animal chromosomes of 5-AZA have been not analysed till now. BrdU, had been previously reported to induce chromatid and isochromatid breaks/gaps located at the junctions between R-positive and -negative bands or peri-centromeric regions of the bovine chromosomes (Di Berardino et al., 1983). The distribution of lesions in the karyotype of healthy, normally fertile cows was estimated to be proportional to the chromosome length and the $1 \mathrm{q} 2.5 / 2.6,2 \mathrm{q} 1.2 /$ 1.3, 2q2.4/2.5, 4q2.6/2.7,12q1.2/1.3, 12q2.2/q3.1, Xp1.5/2.1, Xq2.6/2.7 bands were ascertained to be the most BrdU-expressive sites. On the other hand, our studies performed on the group of subfertile animals have shown the significantly increased frequencies of spontaneous and 5-AZA- and BrdU-dependent breaks/gaps in this group compared to the control one. Our observations revealed also the percentages of No. 1 and X chromosome defects observed to exceed the expected ones (according to their lengths) in the test cows' karyotype. However, in the case of the X only the difference between these values was stated to be statistically significant and evidenced the special X chromosome fragility. Besides, the several chromosome bands (mostly G-negative) such as the 1q3.5 and particularly the Xp2.2, Xq1.2, Xq2.4, Xq3.1 were recognized to be much more unstable in the karyotype of subfertile animals than in the control ones. Moreover, the breaks/gaps percentages observed at the Xq2.4 and Xq3.1 regions were revealed to differ significantly between the groups of cows studied. The excessively damaged X-specific sites found out in the test cows correspond to the spontaneous and previously described BrdU-requiring (p2.2, q2.4) as well as the APC- (q3.1) and -folate-dependent (q2.4) ones (Di Berardino et al., 1983; Llambi et al., 1999; Danielak-Czech and Słota, 2002). The Xp instability has not been pointed out to be associated with any phenotypic changes, whereas the Xq fragility was proved to have some clinical and reproductive consequences. The Xq pericentromeric region defects were described in some cases of baldy calf syndrome in Holstein cows (Uchida et al., 1986). Furthermore, the intensified Xq2.3/2.4 and Xq3.1-specific damages were reported to be of frequent occurrence in the karyotype of Black-and-White, Holstein-Friesian, Japanese Black and Uruguayan Creole cattle with reproductive inefficiency (Hanada and Muramatsu, 1980; Uchida et al., 1986; Llambi and Postiglioni, 1994, 1997; Postiglioni et al., 1996; Rincón et al., 1997; Słota et al., 2000). Fragile X has been mostly observed in cows showing long calving interval, reduced rate of non return for services 
after artificial insemination and increased loss of calves. Our findings confirmed the coexistence of the excessive 5-AZA- and BrdU-dependent chromosome instability, especially at the Xq2.4 and Xq3.1 regions, with the similar reproductive problems in cows. The possible correlation between accumulation of 5-AZA- and BrdU-induced as well as the other fragile sites (especially within X chromosome - Xq22.1, $\mathrm{Xq} 27.3$ ) and reduced foaling rate has been also suggested to exist in mares. The $\mathrm{X}$-specific instability identified in horses has been also reported in rabbits, dogs and humans, demonstrating that chromosome fragility can be preserved between very distantly related mammalian species (Stone et al., 1991; Rønne, 1995).

The BrdU-inducible fragile sites in the Romanov and Booroola sheep karyotype have been reported to be located at the autosomal subcentromeric bands of the 9 as well as presumptive 12 and 20 chromosome pairs, respectively (Cribiu et al., 1991; Matejka et al., 1995). However, the 9q1.1 fragile site carriers were stated to have some reproductive parameters (ovulation rate, litter size, embryonic mortality) on the level similar to control animals. On the other hand, the present study carried out with the old native Polish Heath sheep revealed not only the 9q1.1 but also Xq1.1 and Xq3.2/3.3 region fragility, especially distinct in the group of ewes repeating ineffective matings. Besides, the frequencies of $\mathrm{X}$ chromosome damages observed were determined to be non-proportional (at the statistical level) to the expected one calculated for the $\mathrm{X}$ length. On the basis of the results obtained, the Xq3.2/3.3 5-AZA- and BrdU-sensitive bands were found to correspond to Xq3.3 folate-dependent site as well as to adjoin the Xq3.1 APC-induced one. These fragile sites were recognized to be extremely expressive in the subfertile ewes of this breed in our previous studies (Danielak-Czech and Słota, 2002). Interestingly, the sheep Xq3.1-Xq3.3 unstable region (comprising the 5-AZA- and BrdU-sensitive $\mathrm{Xq3} .2$ site identified in the present studies) is known to demonstrate synteny conservation and segment homology with the fragile cattle Xq2.6 -Xq3.1 region, observable in some cases in the repeat breeding cows (Iannuzzi and Di Meo, 1995; Prakash et al., 1997). Our findings suggest that these bands represent some of the common fragile sites preserved in most Bovidae species.

Numerous fragile sites have been described to occur up to now in the pig karyotype, among them several ones cross-induced by in vitro exposure to folate antagonists and BrdU-Hoechst 33258 (Rønne, 1995). Almost 60\% of them were reported to be involved in reciprocal translocations, common karyotype rearrangement, formed in majority de novo and associated with considerably reduced fertility in this species (about 50\% decreased litter size on an average) (Gustavsson, 1990; Danielak-Czech et al., 1996). Several autosomal unstable regions were unmasked on chromosome 13 (seven fragile sites) and identified as the breakpoints in eight translocations identified in population studies (Long, 1991; Danielak-Czech et al., 1997; Pinton et al., 2000). By contrast, the $\mathrm{X}$-specific fragile sites have been observed rarely and one of them only (Xp2.1) 
was correlated to the translocation breakpoint. In our experiment the significantly higher total percentages of 5-AZA- and BrdU-induced breaks/gaps as well as considerable instability of No. 13 and X chromosome have been shown in the group of sows with decreased reproductive efficiency. However, in the case of the $\mathrm{X}$ only the observed lesions number was determined to significantly exceed the expected frequency in relation to the length. Besides, the 13q4.1 and Xq2.2 sites were recognized to be the most expressive bands in chromosomes of sows from the test group. The 13q4.1 fragile site was stated to be involved in the two different translocations - $(6 ; 13)$ and $(13 ; 17)$ related to decreased prolificacy (Kuokkanen and Mäkinen, 1998; Pinton et al., 2000). Furthermore, the results obtained showed the 5-AZA- and BrdU-sensitive Xq2.2 unstable region to be coincident with the APC-dependent site that in our previous experiment was ascertained to have been highly fragile in subfertile sows (Riggs et al., 1993; Danielak-Czech and Słota, 2002). The described chromosome fragility is suggested to increase frequency of animals with reproductive inefficiency in pig herds.

\section{CONCLUSIONS}

Our findings confirmed that spontaneous chromosome fragility intensified by exposure to mutagen agents may lead in farm animals to negative phenotypic effects, e.g., decreased fertility. The excessive chromosome instability in subfertile cows, ewes and sows, particularly of the X-specific loci, is suggested to result in inappropriate expression of genes determining reproductive traits as well as in increased rate of aneuploid germ cells related to prenatal and perinatal mortality.

\section{REFERENCES}

Bryant P.E., 1997. DNA damage, repair and chromosomal damage. Int. J. Radiat. Biol. 71, 675-680

Cribiu E.P., Durand V., Saget O., Chaffaux S., 1991. Cytogenetic investigations in Booroola Merinos d'Arles sheep (Preliminary reports). In: Major Genes in Reproduction in Sheep. ${ }^{\text {nd }}$ International Workshop, Toulouse, 1990, pp. 305-311

Danielak-Czech B., Kozubska-Sobocińska A., Słota E., Rejduch B., Okularczyk S., 1996. Decrease in pig fertility as result of reciprocal translocations and associated economic effects on the basis of $\operatorname{rcp}(7 ; 13)(q 13 ; q 46)$. J. Appl. Genet. 36, 373-384

Danielak-Czech B., Słota E., 2002. Unstable chromosomal regions in subfertile farm animals. Ann. Anim. Sci. 2, 5-14

Danielak-Czech B., Świtoński M., Słota E., 1997. First identification of reciprocal translocations in Polish pigs. J. Anim. Breed. Genet. 114, 69-78

Di Berardino D., Di Meo G.P., Gallagher D.S., Hayes H., Iannuzzi L., 2001. ISCNDB 2000. International System for Chromosome Nomenclature of Domestic Bovids. Cytogenet. Cell Genet. 92, 283-299 
Di Berardino D., Iannuzzi L., Di Meo G.P., 1983. Localization of the BrdU-induced break sites in bovine chromosomes. Caryologia 36, 285-292

Gustavsson I., 1990. Chromosomes of the pig. Adv. Vet. Sci. Comp. Med. 34, 73-107

Gustavsson I., 1998. Standard karyotype of the domestic pig. Hereditas 109, 151-157

Hanada H., Muramatsu S., 1980. A case of subfertile cow with structural abnormalities of the X-chromosome. Ann. Genet. Sel. Anim. 12, 209-213

Iannuzzi L., Di Meo G.P., 1995. Chromosomal evolution in bovids: a comparison of cattle, sheep and goat G- and R-banded chromosomes and cytogenetic divergences among cattle, goat and river buffalo sex chromosomes. Chromosome Res. 3, 291-299

Kuokkanen M.-T., Mäkinen A., 1988. Reciprocal chromosome translocations (1p; $\left.11 \mathrm{q}^{+}\right)$and $\left(1 \mathrm{p}^{+}\right.$; $15 \mathrm{q}^{-}$) in the domestic pig with reduced litter size. Hereditas 109, 69-73

Llambi S., Guevara K., Rincón G., Nunez R., Arruga M.V., Postiglioni A., 1999. Aphidicolin-induced fragile sites in Bos taurus lymphocyte cultures (a preliminary study). Hung. J. Anim. Prod. 48, $117-120$

Llambi L., Postiglioni A., 1994. Localization of the fragile X chromosome break points in HolsteinFriesian cattle (Bos taurus). Theriogenology 42, 795-802

Llambi S., Postiglioni A., 1997. Frequences and cytomorphological manifestation of sexual X-chromosome fragility (FRA Xq 3.1) in Holstein Friesian cattle. Arch. Zootech. 45, 203-208

Long S.E., 1991. Reciprocal translocations in the pig (Sus scrofa): a review. Vet. Rec. 128, 275-278

Matejka M., Cribiu E.P., Ricordeau G., Eychenne F., Durand V., Lajous D., Darré R., 1995. Evidence for rare heritable fragile site in Romanov sheep chromosome 8. Reprod. Domest. Anim. 25, 220-226

Pinton A., Ducos A., Berland H., Sequela A., Brun-Baronnat C., Darre A., Darre R., Schmitz A., Yerle M., 2000. Chromosomal abnormalities in hypoprolific boars. Hereditas 132, 55-62

Postiglioni A., Llambi S., Gagliardi R., de Bethencourt M., 1996. Genetic characterization of a sample of Uruguayan Creole cattle. I. Cytogenetic characterization of a sample of Uruguayan Creole cattle. Arch. Zootech. 45, 209-213

Prakash B., Olsaker I., Gustavsson I., Chowdhary B.P., 1997. FISH mapping of three bovine cosmids to cattle, goat, sheep and buffalo X chromosomes. Hereditas 126, 115-119

Riggs P.K., Kuczek T., Chrisman C.L., Bidwell C.A., 1993. Analysis of aphidicolin-induced fragility in the domestic pig (Sus scrofa). Cytogenet. Cell Genet. 62, 110-116

Rincón G., Llambi S., Postiglioni A., 1997. Expression of X chromosome fragility in Holstein-Friesian cattle: a preliminary study. Genet. Sel. Evol. 29, 295-401

Rønne M., 1992. Putative fragile sites in the horse karyotype. Hereditas 117, 127-136

Rønne M., 1995. Localization of fragile sites in the karyotype of Sus scrofa domestica: present status. Hereditas 122, 153-162

Rubeš J., Borkovec L., Hořínová Z., Urbanová J., Proroková I., Kulíková L., 1992. Cytogenetic monitoring of farm animals under conditions of environmental pollution. Mutation Res. 283, 199-210

Słota E., Danielak-Czech B., Pietraszewska J., Kozubska-Sobocińska A., 2000. Preliminary identification of the fragile X in two crossbred cows. Vet. Med.-Czech 45, 308-310

Stone D.M., Jacky P.B., Hancock D.D., Prieur D.J., 1991. Chromosomal fragile sites expression in dogs: I. Breed specific differences. Amer. J. Med. Genet. 40, 214-222

Sutherland G.R., Baker E., Richards R.I., 1996. Fragile sites. Encyclopedia Molec. Biol. Molec. Med. 2, 313-318

Sutherland G.R., Parslow M.I., Baker E., 1985. New classes of common fragile sites induced by 5-azacytidine and bromodeoxyuridine. Hum. Genet. 69, 233-237

Uchida I.A., Freeman V., Basrur P., 1986. The fragile X in cattle. Amer. J. Med. Genet. 23, 557-562 


\section{STRESZCZENIE}

\section{Niestabilność chromosomów zwierząt gospodarskich indukowana działaniem mutagenów}

Porównano częstość spontanicznych oraz indukowanych działaniem mutagenów in vitro niestabilnych uszkodzeń chromosomów u krów, maciorek i loch o obniżonej płodności (doświadczalnych), jak również u zwierząt nie wykazujących zaburzeń rozrodu (kontrolnych). Średni procent defektów indukowanych przy zastosowaniu 5-AZA i BrdU różnił się statystycznie między grupami testowymi i kontrolnymi ( $\mathrm{P} \leq 0,01$ u bydła, $\mathrm{P} \leq 0,05$ u owiec i świń). W grupach zwierząt o obniżonej płodności liczba uszkodzeń obserwowanych w niektórych chromosomach przekraczała wartości oczekiwane (oszacowane w odniesieniu do względnej długości chromosomu), jednak tylko w przypadku chromosomu X różniła się istotnie statystycznie. Ponadto, grupa doświadczalna badanych krów różniła się istotnie od grupy kontrolnej pod względem proporcji pęknięć/przewężeń chromatyd w miejscach łamliwych Xq2.4 oraz Xq3.1. Szczególna niestabilność chromosomów zwierząt z zaburzeniami rozrodu, przede wszystkim loci w obrębie chromosomu X, może być przyczyną nieodpowiedniej ekspresji genów determinujących cechy reprodukcyjne, jak również podwyższonego wskaźnika aneuploidalnych komórek rozrodczych i związanej z tym śmiertelności prenatalnej i okołoporodowej. 